AKSIOMA: Jurnal Program Studi Pendidikan Matematika

DOI: https://doi.org/10.24127/ajpm.v9i4.3160

\title{
COMPUTATIONAL THINKING ABILITY STUDENTS BASED ON GENDER IN CALCULUS LEARNING
}

\author{
Triana Harmini' ${ }^{1}$, Pradipta Annurwanda ${ }^{2}$, Siti Suprihatiningsih ${ }^{3}$ \\ 1* Universitas Darussalam Gontor, Ponorogo, Indonesia \\ ${ }^{2,3}$ STKIP Pamane Talino, Landak, Indonesia \\ *Corresponding author. \\ E-mail: triana@unida.gontor.ac.id ${ }^{1 *}$ \\ p.annurwanda@stkippamanetalino.ac.id ${ }^{2)}$ \\ s.suprihatiningsih@stkippamanetalino.ac.id $^{3)}$
}

Received 14 October 2020; Received in revised form 01 December 2020; Accepted 18 December 2020

\begin{abstract}
The purpose of this study was to determine differences in the computational thinking skills of first students of the Department of Informatics Engineering based on genders. This study uses quasi-experimental methods. The subjects in this study were semester two students of the Department of Informatics Engineering in 2019/2020. The research subjects were 34 male students and 23 female students. Methods of data collection using tests and observations. The research instrument used was a computational thinking ability test and an observation sheet. Data analysis using a t-test (independent sample) with analysis prerequisites in normality and homogeneity tests. Test analysis utilizing the help of IBM SPSS Statistics 20. The study of research data shows that there are significant differences between the computational thinking ability of male and female students. The average results of the computational thinking ability test showed that male students' computational thinking ability is better than the female students' computational thinking ability. The male and female students' computational thinking skills reach the generalization stage, where male students can find solutions directly through easy-to-understand and straightforward ideas. Meanwhile, female students can explain the flow and concepts used to solve problems.
\end{abstract}

Keywords: calculus learning; computational thinking; gender

\begin{abstract}
Abstrak
Tujuan penelitian ini adalah untuk mengetahui perbedaan kemampuan berpikir komputasi mahasiswa semester awal jurusan Teknik Informatika berdasarkan jenis kelamin. Penelitian ini menggunakan metode eksperimen semu. Subjek dalam penelitian ini adalah mahasiswa semester 2 jurusan Teknik Informatika tahun ajaran 2019/2020. Subjek penelitian adalah 34 siswa laki-laki dan 23 siswa perempuan. Metode pengumpulan data menggunakan tes dan observasi. Instrumen penelitian yang digunakan adalah tes kemampuan berpikir komputasi dan lembar observasi. Analisis data menggunakan uji-t dengan prasyarat analisis berupa uji normalitas dan homogenitas. Uji analisis menggunakan bantuan IBM SPSS Statistics 20. Hasil penelitian dapat disimpulkan bahwa terdapat perbedaan yang signifikan antara kemampuan berpikir komputasi siswa laki-laki dan perempuan. Hasil rata-rata tes kemampuan berpikir komputasi diperoleh bahwa kemampuan berpikir komputasi siswa laki-laki lebih baik daripada kemampuan berpikir komputasi siswa perempuan. Kemampuan berpikir komputasi mahasiswa putra dan putri mencapai tahap generalisasi, dimana mahasiswa putra mampu mencari penyelesaian secara langsung melalui ide sederhana dan mudah dipahami. Sedangkan mahasiswa putri mampu menjelaskan alur dan konsep yang digunakan untuk menyelesaikan masalah.
\end{abstract}

Kata kunci: berpikir komputasi; jenis kelamin; pembelajaran kalkulus

This is an open access article under the Creative Commons Attribution 4.0 International License 


\section{INTRODUCTION}

Learning is experienced as an internal process that involves several aspects, namely, cognitive, affective, and psychomotor (Qadri et al., 2019). Computational cognitive-oriented thinking in learning can be optimized to provide optimal learning experiences. Computational thinking is an innovative mindset in identifying life phenomena to offer various solutions (Fajri, Muhammad., Yurniawati., Utomo, 2019). Therefore, the importance of thinking ability for students is needed to be able to offer various solutions, mainly to Informatics Engineering students.

One approach to learning that has the potential to improve students' critical thinking skills is Computational Thinking (CT). Computational thinking has been popular in recent years and it is an essential ability for all levels of science in the digital world. Computational thinking in education was first investigated by Papert in 1980 (Pappert, 1980) and popularized by Wing in 2006 (Wing, 2006). Computational thinking is a basic skill and essential part of early education (Shanmugam \& Nadesan, 2019).

Computational thinking is an essential ability to think for students and teachers and provide new ways of thinking to solve problems and develop opportunities (Kawuri et al., 2019). CT is a cognitive problem-solving process or ability, which is possible to develop not only using computer programming (Brackmann et al., 2017). Learning to compute thinking and computer science are inseparable. Both are used interchangeably in daily life and in principle intended to educate students in learning and to use the principles of mathematical calculation (Cansu \&
Cansu, 2019). Computational thinking can help scientists and engineers in simulating phenomena, analyzing data sets, and learn the many quantitative relationships that correspond to scientific disciplines (Haines et al., 2019)

One of the influences on computational thinking ability is gender. It is in line with research conducted in 2017, which states that in solving problems, gender can also affect students' computational thinking processes (Alfina, 2017). Gender can affect students' mathematical abilities due to biological differences in the child's brain (Andriani \& Nurjaman, 2018). Gender differences make different ways of thinking, learning, and conceptualization processes (Dilla et al., 2018). The research carried out renewal on students' computational thinking skills based on gender in the Informatics Engineering study program students.

Based on preliminary surveys that have conducted, students at Universitas Darussalam Gontor graduate from Pondok Modern Darussalam Gontor who have low mathematical abilities specially for female students. The average value of the computational thinking ability of female students is lower than the computational thinking ability of male students. It also happens on other campuses, for example, research that has conducted at the University of Nusa Cendana (Samo, 2017). Therefore, it is necessary to know the computational thinking skills of early students as the basis of the Informatics Engineering students' thinking patterns based on gender because male and female students have very different thinking patterns. Gender differences lead to differences in 
ways of thinking and ways of learning. Men and women have many differences when it comes to solving a problem. Therefore, based on the description above, this study aims to determine the differences in students' computational thinking ability of the Departement of Informatics Engineering study based on gender.

\section{METHOD}

This study uses quasiexperimental methods. The subjects in this study were second-semester students of the Informatics Engineering Study Program in the academic year 2019/2020. This study was conducted at the beginning of the even semester of 2019/2020. The research subjects were 34 male students and 23 female students. Methods of data collection using tests and observations. The research instrument used was a computational thinking ability test and an observation sheet.

The researcher conducted three meetings in learning calculus two subjects. Observer observed the learning process. At the end of the learning process, the students will give a computational thinking ability test. Students' initial ability is known based on the final score data of students in the Calculus 1 course. The researcher uses the initial ability data to determine the balance of male and female students' initial grades.

Table 1. Indicators of students computational thinking process.

\begin{tabular}{|c|c|c|}
\hline No & Steps & Indicators \\
\hline 1 & Decomposition & $\begin{array}{l}\text { - Able to identify information that is known from the problem } \\
\text { given } \\
\text { - Ready to simplify complex issues into simple questions and } \\
\text { solve them thoroughly and comprehensively } \\
\text { - Able to come up with simple ideas and easy to understand to } \\
\text { solve problems }\end{array}$ \\
\hline 2 & $\begin{array}{l}\text { Abstraction or } \\
\text { pattern recognition }\end{array}$ & $\begin{array}{l}\text { - Able to recognize patterns or characteristics that are the } \\
\text { same/different in solving problems given to build a solution } \\
\text { - Ready to find trends related to other issues presented. } \\
\text { - Able to identify patterns, similarities, and relationships of given } \\
\text { problems }\end{array}$ \\
\hline 3 & $\begin{array}{l}\text { Composing } \\
\text { algorithms }\end{array}$ & $\begin{array}{l}\text { - Able to mention logical steps that are used to arrange a solution } \\
\text { of a given problem } \\
\text { - Ready to find a way to obtain a flow of completion through a } \\
\text { clear definition of the completion steps developed } \\
\text { - Able to get a solution through a clear description of the measures } \\
\text { taken }\end{array}$ \\
\hline 4 & Generalizations & $\begin{array}{l}\text { - Able to mention the general pattern of similarities/differences } \\
\text { found in the given problem } \\
\text { - Able to conclude patterns found in the given problem } \\
\text { - Ready to find a fast way to solve new challenges based on } \\
\text { solving similar problems before }\end{array}$ \\
\hline
\end{tabular}


The initial ability value was analyzed using the t-test with analysis prerequisites in normality and homogeneity tests. The normality test used the Kolmogorov Smirnov test, and the results showed that the initial ability data for male and female students were normally distributed. For the homogeneity test using the Levene test and the results obtained, the probability value $=0.523>0.05$ so that the two data have the same variance. Furthermore, to determine the significance of the difference in the mean data of students' initial ability, a t-test carried out shows that the significant value of $t$ is $0.474>$ 0.025 , which means that there is no significant difference in the data on the initial ability of male and female students. It can conclude that male and female students have the same initial ability.

Computational thinking ability test in the form of problem description totalling four questions the dimensions of computational thinking ability, including decomposition, abstraction or pattern recognition, composing algorithms, and generalizations. The test questions used were validated by two mathematics education lecturers to find out the suitability of the problems with the stages of computational thinking ability. Observation sheets are used during the learning process to determine students' computational thinking skills based on the four steps of computational thinking ability-observations made during the learning process. The computational thinking process indicators used in this study are presented in Table 1.

Data analysis was carried out qualitatively and quantitatively. Qualitative analysis is used to analyze the computational thinking ability of male and female students through observation during learning. Quantitative analysis was conducted to determine differences in the computational thinking abilities of male and female students. Quantitative analysis based on the results of computational thinking ability tests. Data analysis using a t-test (independent sample) with analysis prerequisites in the form of normality and homogeneity tests. Test analysis using IBM SPSS Statistics 20.

\section{RESULT AND DISCUSSION}

The results of this study are in the form of the effects of tests of students' computational thinking skills and observations. This research was conducted on Calculus subject learning for Function derivatives material. The study was conducted during 4 meetings. Representations are made during the learning process based on observation sheets that have been prepared by researchers based on four stages of computational thinking ability. Observations were made by two observers who are lecturers in the Informatics Engineering Study Program. Observation results indicate that male students have been able to demonstrate computational thinking skills to the generalization stage. However, at the decomposition stage, male students tend to skip it. In solving problems, male students tend not to identify the information asked of the provided issues but instead, try to find solutions directly to simple and easily understood ideas to solve problems.

The results of observations for female students are known that the computational thinking ability of female students has reached the stage of generalization as well. However, female 
students tend to be more diligent and conscientious in solving problems. At the scene of generalization can be seen when working on different issues with examples but have the same pattern of relationships, female students can solve them using the same model of work. Female students have been able to explain the flow and concepts used to solve problems.
The results of students' computational thinking ability tests are test scores on the Calculus course. In general, the average mathematical thinking ability of male and female students is different. A summary of the results of students' computational thinking ability tests is presented in Table 2.

Table 2. Summary of descriptive analysis computational thinking ability test.

\begin{tabular}{ccc}
\hline Statistics & $\begin{array}{c}\text { Computational Thinking } \\
\text { Ability Female Students }\end{array}$ & $\begin{array}{c}\text { Computational Thinking } \\
\text { Ability Male Students }\end{array}$ \\
\hline Mean & 65.52 & 74.09 \\
Standard Deviation & 13.02 & 10.879 \\
Minimum & 31 & 56 \\
Maximum & 95 & 96 \\
\hline
\end{tabular}

From Table 2 it can be seen that the average value of the computational thinking ability of male students is higher than the computational thinking ability of female students. It means that there are differences in computational thinking skills between male and female students. To find out the different significance of the computational thinking abilities of male and female students, a statistical test was performed using the t-test. Formally the statistical hypothesis (Ho) and research hypothesis $\left(\mathrm{H}_{1}\right)$ are as follows: Ho: There is no significant difference in the computational thinking ability of male and female students
$\mathrm{H}_{1}$ : there is a significant difference in the computational thinking ability of male and female students

Hypothesis testing criteria that Ho is rejected if $\mathrm{t}$-count $<\mathrm{t}$-table or $\mathrm{t}$-count $<$ t-table or p-value (sig) $<0.025$. To conduct a t-test analysis, an analysis prerequisite test is needed in the form of normality and homogeneity data tests. Test the normality of both data by using the Kolmogorov-Smirnov and ShapiroWilk test with the test criteria that the data are normally distributed if the $\mathrm{p}$ value $(\mathrm{Sig})>0.05$. A summary of normality test results using IBM SPSS Statistics 20 is presented in Table 3.

Table 3. Summary of Normality test results.

\begin{tabular}{lccrrrr}
\hline & \multicolumn{2}{c}{ Kolmogorov-Smirnov } & \multicolumn{3}{c}{ Shapiro-Wilk } \\
& Statistic & \multicolumn{1}{c}{ df } & \multicolumn{1}{c}{ Sig. } & Statistic & df & \multicolumn{1}{c}{ Sig. } \\
\hline Male & .169 & 23 & .086 & .956 & 23 & .384 \\
Female & .127 & 23 & $.200^{*}$ & .966 & 23 & .596 \\
\hline
\end{tabular}

*. It is a lower bound of the true significance.

a. Lilliefors Significance Correction 
From Table 3 it can be seen that from the Kolmogorov-Smirnov and Shapiro-Wilk test data on the computational thinking ability of male students has a Sig value higher than 0.05 which means the data on the computational thinking ability of male students is usually distributed. In the data of female students 'computational thinking ability data has a Sig value higher than 0.05 , which means the data on female students' computational thinking ability is usually distributed. Analysis prerequisites for the normal distribution are met. Because both data are independent, the data must achieve homogeneity. Homogeneity test data is done by the Levene test with the test criteria that the information is said to be homogeneous if the Sig value $>0.05$. A summary of the homogeneity test results is presented in Table 4.
Table 4. Summary of Homogeneity test results.

\begin{tabular}{cccc}
\hline $\begin{array}{c}\text { Levene } \\
\text { Statistic }\end{array}$ & df1 & df2 & Sig. \\
\hline .270 & 1 & 55 & .605 \\
\hline
\end{tabular}

From Table 4, it can be seen that the Levene test results obtained Sig values of $0.605>0.05$ which means that both data come from comparable data. From these results, it can be concluded that the analysis prerequisite tests for the t-test have been fulfilled. Then the hypothesis test is performed using the $\mathrm{t}$ test. This test is used to determine the significance of the difference in the average results of computational thinking skills tests between male and female students. A summary of the results of the hypothesis test using the t-test (independent sample) is presented in Table 5.

Table 5. Summary of t-test Results

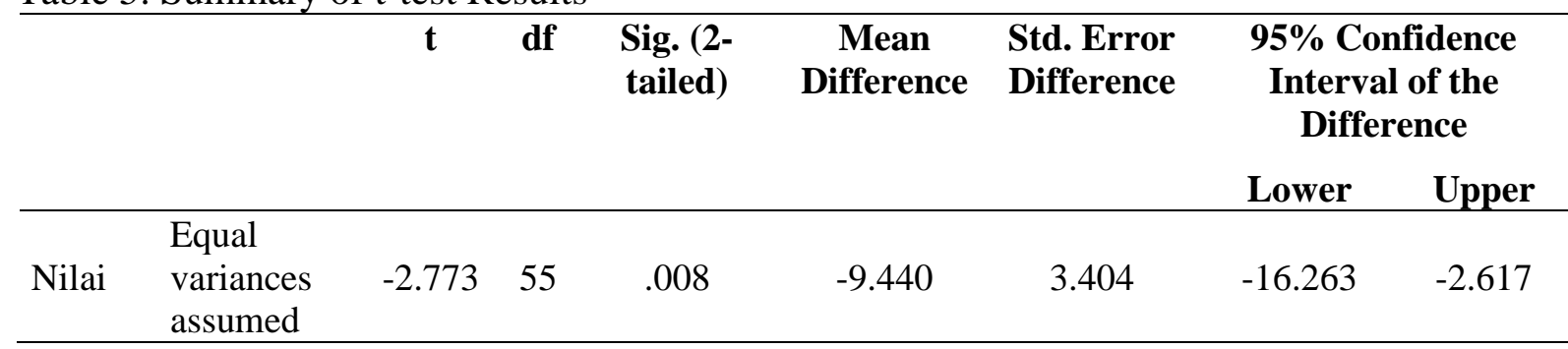

Based on the t-test results in Table 5 it can be seen that the Sig value of $0.008<0.025$, it can be concluded that Ho is rejected and $\mathrm{H} 1$ is accepted. It means that there are significant differences between the computational thinking abilities of male and female students. From the results of the average computational thinking ability of male students is higher than the average computational thinking ability of female students. It can be concluded that the results of the computational thinking ability of male students are better than the strength of female students' computational thinking.

The observations show that male and female students have been able to demonstrate computational thinking skills up to the generalization stage. Male students can find solutions directly through easy-to-understand and straightforward ideas to solve problems without writing down what is known 
beforehand, while female students have been able to explain the flow and concepts used to solve problems. This is following the results of Setyawati's research (2020) which states that male students tend to write only the most important elements of known things, while female students write in detail, clearly and take a long time to write all known elements on the problem whether it is important or not (Setyawati et al., 2020). Women can make clear and complete plans and steps according to the concept (Simanjuntak et al., 2019). Women could carry out projects and check work returns even though the results were incomplete (Aini, 2017).

Boys and girls have differences in solving mathematical problems. Male students are more likely not to identify early information to solve problems. Still, they can find fast ways to solve new questions based on solving previous similar situations. Meanwhile, female students were more diligent in identifying initial information. Still, female students tended to solve problems procedurally so that they were not able to determine patterns or quick ways of solving problems. Women tend to be conscientious, systematic, detailed than men (Davita \& Pujiastuti, 2020; Kalily \& Juhaevah, 2018)

Computational thinking ability is the ability to think so to teach the ability to think can be done through learning activities. In the learning process, computational thinking skills can be integrated into mathematics learning. Computational thinking and mathematics have a reciprocal relationship where computational thinking is used to enrich mathematics and science learning (Nuraisa et al., 2019). Computational thinking ability and mathematical thinking ability are an essential combination to support students' conceptual understanding of mathematics. The development of concepts and students' computational thinking skills can provide a realistic perspective on how mathematics can be applied in the professional world and used in real life (Zahid, 2020). In PISA 2021, the measurement of computational thinking aspects is included in the field of mathematics assessment (OECD, 2020).

The difference between men and women in learning mathematics, that men are superior in reasoning, whereas women are superior in accuracy, precision, caution, and attention (Mawaddah et al., 2018). The influence of gender factors in mathematical ability is caused due to biological differences in male and female brains. Where women, in general, are superior in the field of language and writing while men are superior in mathematics because of better spatial ability (Dilla et al., 2018).

In this study, the male students 'computational thinking ability is better than the female students' computational thinking ability. Spatial and computational abilities between male and female students have significant differences because male students have superior arithmatics reasoning abilities (Geary et al., 2000). It is influenced by the strength of male students to be more intellectual, abstract, and objective so that in solving problems male students tend to be able to understand issues by calculations, evaluate the compatibility between computational tools and techniques and challenges, and implement computational strategies. The essence of computational thinking is to determine 
the solution of complex problems into problems that can be understood by using a precise sequence of steps (algorithm), finding patterns to be applied to other issues (Yadav et al., 2016).

\section{CONCLUSION AND SUGGESTION}

Based on the results of the analysis of research data, it can be concluded that there is a significant difference between the computational thinking ability of male and female students. The average results of the computational thinking ability test obtained that the computational thinking ability of male students is better than the female students' computational thinking ability. Observation results show that during the Calculus learning process, male and female students can demonstrate computational thinking skills up to the generalization stage. Male students tend to have abstract, complex, objective, and logical characteristics. Girls students can conclude patterns found in the given problems. Male and female students have been able to find a solution to a problem based on a model on solving a previous issue.

This research was conducted at private universities with students' ability to think less computationally so that further research development could be carried out at universities with better student abilities. The study in this study was limited to the students' computational thinking ability which, was reviewed based on gender differences. Therefore, other researchers can study more deeply about students' computational thinking skills in solving other problems with a different view.

\section{REFERENCES}

Aini, K. N. (2017). Proses berpikir mahasiswa laki-laki dan perempuan dengan gaya kognitif field independent dalam memecahkan masalah. Inspiramatika, 3(1), 16-23. http://e-

jurnal.unisda.ac.id/index.php/Inspira matika/article/view/166

Alfina, A. (2017). Berpikir Komputasional Siswa Dalam Menyelesaikan Masalah Yang Berkaitan Dengan Aritmetika Sosial Ditinjau Dari Gender. SimkiTechsain, 01(04).

Andriani, D., \& Nurjaman, A. (2018). Analisis Kemampuan Pemahaman Konsep Materi Segitiga dan Segiempat pada Siswa SMP. Jurnal Pembelajaran Matematika Inovatif, 1(2), 1015-1026. https://doi.org/10.22460/jpmi.v1i3.2 19-228

Brackmann, C. P., Moreno-León, J., Román-González, M., Casali, A., Robles, G., \& Barone, D. (2017). Development of computational thinking skills through unplugged activities in primary school. $A C M$ International Conference Proceeding Series, January 2018, 65-72.

https://doi.org/10.1145/3137065.313 7069

Cansu, F. K., \& Cansu, S. K. (2019). An Overview of Computational Thinking. International Journal of Computer Science Education in Schools, 3(1), 17-30. https://doi.org/10.21585/ijcses.v3i1. 53 
Davita, P. W. C., \& Pujiastuti, H. (2020). Anallisis Kemampuan Pemecahan Masalah Matematika Ditinjau Dari Gender. Kreano, Jurnal Matematika Kreatif-Inovatif, 11(1), 110-117. https://doi.org/10.15294/kreano.v11i 1.23601

Dilla, S. C., Hidayat, W., \& Rohaeti, E. E. (2018). Faktor gender dan resiliensi dalam pencapaian kemampuan berpikir kreatif matematis siswa SMA. Journal of Medives, 2(1), 129-136.

Fajri, Muhammad., Yurniawati., Utomo, E. (2019). Computational Thinking, Mathematical Thinking Berorientasi Gaya Kognitif Pada Pembelajaran Matematika Di Sekolah Dasar. Dinamika Matematika Sekolah Dasar 1 (1), 1-18, 1(1), 1-18.

Geary, D. C., Saults, S. J., Liu, F., \& Hoard, M. K. (2000). Sex Differences in Spatial Cognition, Computational Fluency, and Arithmetical Reasoning. Journal of Experimental Child Psychology, 77(4), 337-353. https://doi.org/10.1006/jecp.2000.25 94

Haines, S., Krach, M., Pustaka, A., Li, Q., \& Richman, L. (2019). The Effects of Computational Thinking Professional Development on STEM Teachers' Perceptions and Pedagogical Practices. Athens Journal of Sciences, 6(2), 97-122. https://doi.org/10.30958/ajs.6-2-2

Kalily, S., \& Juhaevah, F. (2018). Analisis Kemampuan Berpikir Kritis Siswa Kelas X SMA dalam Menyelesaikan Masalah Identitas Trigonometri Ditinjau Dari Gender.
Jurnal Matematika Dan Pembelajaran, 6(2), 111-126.

Kawuri, K. R., Budiharti, R., \& Fauzi, A. (2019). Penerapan Computational Thinking untuk Meningkatkan Kemampuan Berpikir Kritis Siswa Kelas X MIA 9 SMA Negeri 1 Surakarta pada Materi Usaha dan Energi 6. Jurnal Materi Dan Pembelajaran Fisika (JMPF), 9(2), 116-121.

https://jurnal.uns.ac.id/jmpf/article/vi ew/38623

Mawaddah, Ahmad, A., \& Duskri, M. (2018). Gender differences of mathematical critical thinking skills of secondary school students. Journal of Physics: Conference Series, 1088. https://doi.org/10.1088/17426596/1088/1/012054

Nuraisa, D., Azizah, A. N., Nopitasari, D., \& Maharani, S. (2019). Exploring Students Computational Thinking based on Self-Regulated Learning in the Solution of Linear Program Problem. JIPM (Jurnal Ilmiah Pendidikan Matematika), $8(1)$ 30. https://doi.org/10.25273/jipm.v8i1.4 871

OECD. (2020). Pisa 2021 Mathematics Framework ( Draft ). November 2018.

Pappert, S. (1980). Mindstorms: Children, Computers, and Powerful Ideas. Basic Book, Inc.

Qadri, L., Ikhsan, M., \& Yusrizal, Y. (2019). Mathematical Creative Thinking Ability for Students Through REACT Strategies. 
AKSIOMA: Jurnal Program Studi Pendidikan Matematika Volume 9, No. 4, 2020, 977-986

DOI: https://doi.org/10.24127/ajpm.v9i4.3160

International Journal for Educational and Vocational Studies, 1(1), 58. https://doi.org/10.29103/ijevs.v1i1.1 483

Samo, D. D. (2017). Kemampuan pemecahan masalah matematika mahasiswa tahun pertama dalam memecahkan masalah geometri konteks budaya. Jurnal Riset Pendidikan Matematika, 4(2), 141. https://doi.org/10.21831/jrpm.v4i2.1 3470

Setyawati, D. U., Febrilia, B. R. A., \& Nissa, I. C. (2020). Profil Kemampuan Berpikir Kritis Mahasiswa dalam Menyelesaikan Soal Pemecahan Masalah Matematika Ditinjau dari Jenis Kelamin. Jurnal Didaktik Matematika, 7(1), 90-104. https://doi.org/10.24815/jdm.v7i1.15 709

Shanmugam, L., \& Nadesan, G. (2019). An Innovative Module for Learning Computational Thinking Skills among Undergraduate Students. International Journal of Academic
Research in Progressive Education and Development, 8(4), 116-129. https://doi.org/10.6007/IJARPED/v8 $-\mathrm{i} 4 / 6440$

Simanjuntak, E., Hia, Y., \& Manurung, N. (2019). Analisis Kemampuan Berpikir Kreatif dalam Pemecahan Masalah ditinjau dari Perbedaan Gender. School Education Journal, 9(3), 213-220.

Wing. (2006). Explanation-based learning. COMMUNICATIONS OF THE ACM, 49(3), 68-1-68-18.

Yadav, A., Hong, H., \& Stephenson, C. (2016). Computational Thinking for All: Pedagogical Approaches to Embedding 21st Century Problem Solving in K-12 Classrooms. TechTrends, 60(6), 565-568. https://doi.org/10.1007/s11528-0160087-7

Zahid, M. Z. (2020). bidang matematika Telaah kerangka kerja PISA 2021: era integrasi computational thinking dalam bidang matematika. 3(March 2020), 706-713. 